\title{
Ecology of Lutzomyia longipalpis and Lutzomyia migonei in an endemic area for visceral leishmaniasis
}

\author{
Ecologia de Lutzomyia longipalpis e Lutzomyia migonei em uma área endêmica para Leishmaniose Visceral
}

Rafaella Albuquerque Silva ${ }^{1,2}$; Fabricio Kassio Moura Santos ${ }^{1}$; Lindemberg Caranha de Sousa ${ }^{1}$; Elizabeth Ferreira Rangel ${ }^{3}$; Claudia Maria Leal Bevilaqua ${ }^{2 *}$

\author{
${ }^{1}$ Núcleo de Controle de Vetores, Secretaria da Saúde do Estado do Ceará, Fortaleza, CE, Brasil \\ ${ }^{2}$ Laboratório de Doenças Parasitárias, Programa de Pós-graduação em Ciências Veterinárias, Universidade Estadual do Ceará - UECE, \\ Fortaleza, CE, Brasil \\ ${ }^{3}$ Laboratório de Transmissores das Leishmanioses, Instituto Oswaldo Cruz, Rio de Janeiro, RJ, Brasil
}

Received March 26, 2014

Accepted May 22, 2014

\begin{abstract}
The main vector for visceral leishmaniasis (VL) in Brazil is Lutzomyia longipalpis. However, the absence of L. longipalpis in a region of autochthonous VL demonstrates the participation of other species in the transmission of the parasite. Studies conducted in La Banda, Argentina, and São Vicente Férrer, Pernambuco State, Brazil, have correlated the absence of $L$. longipalpis and the presence of L. migonei with autochthonous cases of VL. In São Vicente Férrer, Pernambuco, there was evidence for the natural infection of L. migonei with Leishmania infantum chagasi. Thus, the objective of this work was to assess the ecology of the sand flies L. longipalpis and L. migonei in Fortaleza, an endemic area for VL. Insect capture was conducted at 22 sampling points distributed across four regions of Fortaleza. In total, 32,403 sand flies were captured; of these, 18,166 (56\%) were identified as L. longipalpis and 14,237 (44\%) as L. migonei. There were significant density differences found between the vectors at each sampling site (indoors and outdoors) ( $\mathrm{p}<0.0001$ ). These findings confirm that L. migonei and L. longipalpis are distributed throughout Fortaleza, where they have adapted to an indoor environment, and suggest that L. migonei may share the role as a vector with L. longipalpis in the transmission of VL in Fortaleza.
\end{abstract}

Keywords: Lutzomyia longipalpis, Lutzomyia migonei, visceral leishmaniasis, Fortaleza.

\section{Resumo}

O principal vetor de leishmaniose visceral (LV) no Brasil é Lutzomyia longipalpis. Entretanto, a ausência de L. longipalpis em área com casos autóctones de LV demonstra a existência de outras espécies na transmissão dessa doença. Estudo realizado na cidade de La Banda, Argentina, e São Vicente Férrer, Brasil, correlacionou a ausência de L. longipalpis e a presença de Lutzomyia migonei com casos autóctones de LV. Em São Vicente Férrer, foi comprovada a infecção natural de L. migonei por Leishmania infantum chagasi. Dessa forma, o objetivo deste trabalho foi avaliar a ecologia dos flebotomíneos L. longipalpis e L. migonei no município de Fortaleza, área endêmica para LV. A captura de flebotomíneos foi realizada em 22 pontos de coleta distribuídos nas quatro regiôes do município de Fortaleza. No total, foram capturados 32.403 flebotomíneos. Destes, 18.166 (56\%) eram da espécie L. longipalpis e 14.237 (44\%) eram L. migonei. Houve diferença significativa de densidade entre os vetores em cada local de captura (intra e peri) ( $<<0,0001)$. Esses achados confirmam que, na cidade de Fortaleza, L. migonei e L. longipalpis estão bem distribuídos, bem como adaptados ao ambiente intradomiciliar e que L. migonei, possivelmente, compartilhe com L. longipalpis o papel de vetor da LV em Fortaleza.

Palavras-chave: Lutzomyia longipalpis, Lutzomyia migonei, leishmaniose visceral, Fortaleza. 


\section{Introduction}

Brazil accounts for approximately $90 \%$ of the reported cases of visceral leishmaniasis (VL) on the South American continent. The northeastern area of Brazil is considered most representative, with $48 \%$ of the cases (ZERPA et al., 2003; BERN et al., 2008; BRASIL, 2009). In the northeast, the state of Ceará is endemic for VL and is considered a priority for health surveillance and control by the Ministry of Health. The cities with the highest incidence of VL are Fortaleza, Sobral, Juazeiro, Barbalha and Caucaia. However, Fortaleza is the only city classified as an area of intense transmission, as 218 and 262 cases were reported in 2009 and 2010, respectively. Based on studies of vector competence and capacity, the main vector for VL in Brazil is Lutzomyia longipalpis (DEANE, 1956; LAINSON; RANGEL, 2005). However, studies conducted in Corumbá, State of Mato Grosso do Sul, in the Brazilian Midwest found Lutzomyia cruzi as the most prevalent species, both indoors and outdoors (GALATI et al., 1997). The natural infection of $L$. cruzi with Leishmania infantum (syn Leishmania chagasi) has also been documented in Corumbá (SANTOS et al., 1998). Although L. cruzi has become an accepted vector for VL, its range is restricted to Mato Grosso (RIBEIRO et al., 2007), Mato Grosso do Sul and Goiás (GALATI et al., 1997; GALATI, 2003).

More recently, studies from La Banda, Argentina, have correlated the absence of $L$. longipalpis and the presence of L. migonei with autochthonous VL cases (SALOMÓN et al., 2010). A similar pattern has been demonstrated in San Vicente Férrer, State of Pernambuco, in northeastern Brazil. In this study, the natural infection of $L$. migonei with $L$. (L.) infantum chagasi was documented, highlighting the potential role of this vector for parasite transmission in these areas (CARVALHO et al., 2010). The objective of this study was to gain insight into the transmission of L. infantum in Fortaleza by studying the ecology of L. longipalpis and L. migonei through the evaluation of entomological indicators of $\mathrm{VL}$ and discussing whether these sympatric species may share the role as vectors for $L$. infantum in urban areas.

\section{Materials and Methods}

\section{Study area}

The study was conducted in Fortaleza, the capital of Ceará State, which is located along the Atlantic coast at an average elevation of $21 \mathrm{~m}$, covers an area of $313.8 \mathrm{~km}^{2}$ and has 2,505,552 inhabitants. Fortaleza has the highest population density, at 8,001 inhabitants per $\mathrm{km}^{2}$. The average annual temperature is $26^{\circ} \mathrm{C}$. December and January are the warmest months, and July is the coolest, though the temperature differences between months are minor. The average rainfall is $1,600 \mathrm{~mm}$ and is concentrated between February and May. The wettest month is April $(348 \mathrm{~mm})$, and the driest is November $(13 \mathrm{~mm})$. The vegetation is typical of coastal areas and consists of mangroves and restingas. The remaining vegetation in the city is variable but includes many fruit trees (IBGE, 2008).

\section{Capture of sand flies}

Phlebotomine sand flies were captured from February of 2009 to January of 2010. The captures were performed in the following 22 districts within Fortaleza: the northern districts of Quitino Cunha (QC), Alvaro Weyne (AW), Farias Brito (FB), Aldeota (AD) and Jardim America (JA); the southern districts of Mondumbim (MD), Passaré (PA), Cajazeiras (CA), Planalto Airton Sena (PAS), Prefeito José Walter (PJW), Conjunto Palmeira (CP) and Paupina (PU); the eastern districts of Vicente Pizon (VP), Jardim das Oliveiras (JD), Edson Queiroz I (EDI), Edson Queiroz II (EDII), Cambeba (CB) and Lagoa Redonda (LR) and the western districts of Conjunto Ceara II (CCII), Democrito Rocha (DR), Siqueira (SQ) and Vila Manuel Sátiro (VMS) (Figure 1).

The districts were chosen according to the reported number of VL cases in the past 5 years and in accordance with features suggestive of vector presence, such as fruit trees, livestock and organic matter accumulation, as evaluated by environmental characterization forms. The captures were performed over 12 months using CDC light traps (SUDIA; CHAMBERLAIN, 1962) that were armed for four consecutive nights per month from $6 \mathrm{pm}$ to $6 \mathrm{am}$. One collection point was chosen in each district. The traps were placed near animal shelters when possible, and two were placed at each residence, with one trap inside and another outside of the home (BRASIL, 2006). A total of 44 traps were used, with a minimum distance between sampling points (districts) of $1 \mathrm{~km}$.

\section{Identification of phlebotomine sand flies}

The collected sandflies were sent to the Entomology Laboratory of the Health Secretariat of Ceará State for identification. The specimens were killed with ethyl acetate and placed in small Petri dishes in a solution of $10 \%$ potassium hydroxide for 2 hours. The sand flies were then submerged in acetic acid for 15 minutes and in lactophenol for 24 hours. The specimens were mounted onto slides with coverslips using Berlese fluid (VILELA et al., 2003). Males and females were classified using the key of Young and Duncan (1994).

\section{Data from human and canine visceral leishmaniasis}

Data relating to human and canine cases from February 2009 to January 2010 were obtained from the Secretary of Health and the Zoonosis Control Center of Fortaleza, respectively.

\section{Statistical analysis}

The index of home infestation (IID) and the relative abundance (RA) were calculated using the following formulas (BRASIL, 2006):

IID = Total households by positive sort/search site/technical $\times 100 \div$ Number of local searches;

$\mathrm{RA}=$ Number of L. longipalpis or L. migonei collected by household (outdoors or indoors) $\div$ Total number of households surveyed (outdoors or indoors). 


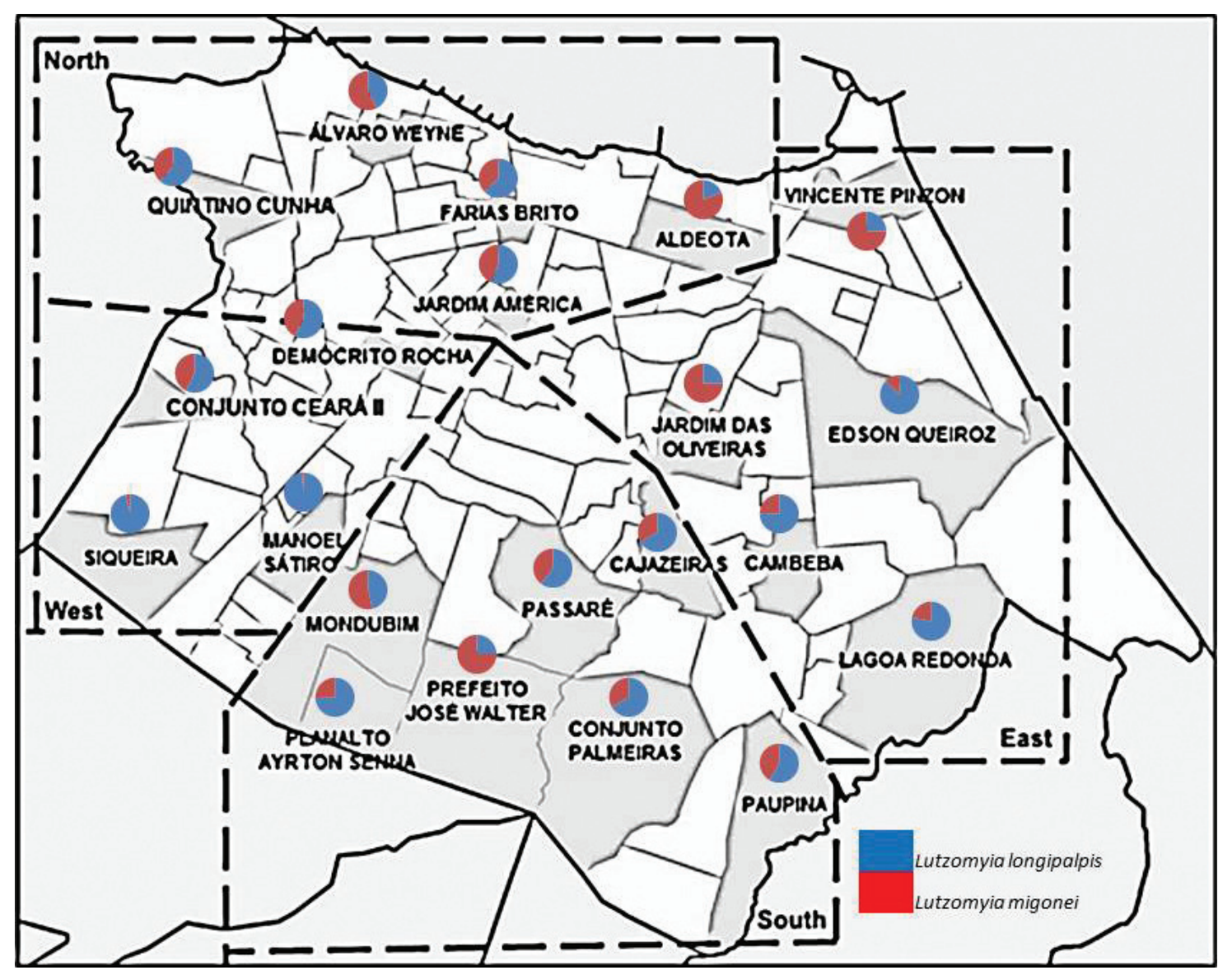

Figure 1. Distribution of Lutzomyia longipalpis and Lutzomyia migonei by collection point (neighborhood) in Fortaleza, Ceará, Brazil.

The analysis of the number of sand flies in relation to the local site characteristics (indoor and outdoor) and species (L. longipalpis and L. migonei) was performed using a generalized mixed model with Poisson distribution and a logarithmic link function, considering the residence as a random factor (DEMIDENKO, 2004). As the interactive effect between the two factors (location and species), a significant adjustment of the models with a single factor for each level of the other was performed. The significance level was 5\%.

Relationships between the human or canine cases and sand fly density were determined using a Pearson correlation coefficient.

\section{Results}

From February 2009 to January 2010, 32,403 sand flies were captured. Of these, 18,166 (56\%) were identified as L. longipalpis and 14,237 (44\%) as L. migonei (Table 1). The presence of both species was confirmed in each neighborhood (Figure 1), though the sand fly density was heterogeneous (Table 1), ranging from 112.23 insects per trap in Farias Brito (FB) to 0.04 in Vicente Pizon (VP). The environmental characterization of each collection point is shown in Table 2. All sampling sites showed abundant vegetation, composed mainly of fruit trees. Regarding the presence of domestic animals, dogs and birds were commonly found in collection points. The index of home infestation in Fortaleza was $90.90 \%$ indoors and $95.45 \%$ outdoors for both species.
In Fortaleza, the relative abundance (RA) of $L$. longipalpis flies per household was 510 indoors and 315.72 outdoors. For L. migonei, the RA was 306.04 indoors and 342.90 outdoors.

Significant differences were observed between the two species, L. migonei and L. longipalpis, in each location (indoor and outdoor) $(\mathrm{p}<0.0001)$ and between the two sites for each species, $\mathrm{p}=0.0012$ and $<0.0001$, respectively (Figure 2 ).

There was no correlation between the number of human and canine VL cases and the sand fly density (L. longipalpis and L. migonei) (Tables 3 and 4).

\section{Lutzomyia longipalpis}

In this study, 18,166 specimens of $L$. longipalpis were captured; $11,220(61.76 \%)$ were caught indoors, and 6,946 (38.24\%) were caught outdoors (Table 1).

Significant differences in the density of $L$. longipalpis between sites and indoors and outdoors were observed, $\mathrm{p}<0.0001$ (Figure 2).

The district with the highest density of $L$. longipalpis was Farias Brito (FB), located in the northern region: the densities were 5.189 (46.25\%) indoors and 1.575 (22.67\%) outdoors. Lower densities were found in the district of Vicente Pizon, located in the eastern region, with values of $0(0 \%)$ indoors and $1(0.01 \%)$ outdoors (Table 1 . The predominant sex was male, and the male/ female ratio was 1.85 . 


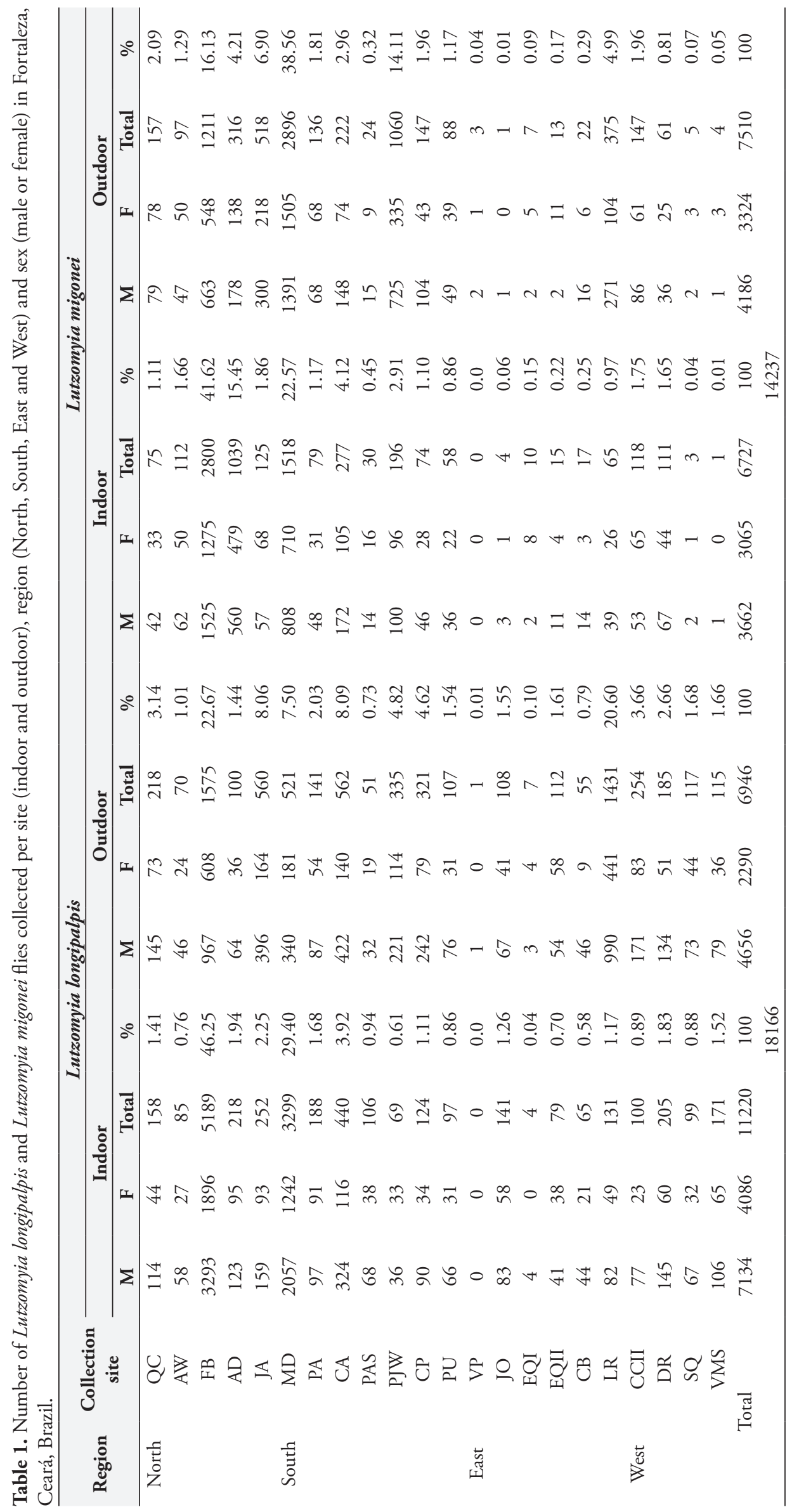


Table 2. Environmental characteristics of sites, in Fortaleza, Ceará, Brazil.

\begin{tabular}{|c|c|c|c|c|c|c|c|c|c|c|}
\hline \multirow[b]{2}{*}{ Collection site } & \multicolumn{7}{|c|}{ DOMESTIC ANIMALS } & \multicolumn{3}{|c|}{ VEGETATION } \\
\hline & Canine & Feline & Porcine & Veal & Equine & Bird & Others & $\begin{array}{c}\text { Vegetable } \\
\text { garden }\end{array}$ & Garden & $\begin{array}{l}\text { Fruit } \\
\text { trees }\end{array}$ \\
\hline Aldeota & & $\mathrm{X}$ & & & & & Tamarin & & $\mathrm{X}$ & $\mathrm{X}$ \\
\hline Álv. Weyne & $\mathrm{X}$ & & & & & $\mathrm{X}$ & & & & $\mathrm{X}$ \\
\hline Cajazeiras & $\mathrm{X}$ & & & & & $\mathrm{X}$ & & & & $\mathrm{X}$ \\
\hline Cambeba & $\mathrm{X}$ & & & $\mathrm{X}$ & & $\mathrm{X}$ & & & & $\mathrm{X}$ \\
\hline Conj. Ceará II & & & & & & $\mathrm{X}$ & & & & $\mathrm{X}$ \\
\hline Conj. Palmeira & $\mathrm{X}$ & & & $\mathrm{X}$ & & $\mathrm{X}$ & & & & $\mathrm{X}$ \\
\hline Demócrito Rocha & $\mathrm{X}$ & & & & & & & & & $\mathrm{X}$ \\
\hline Ed Queiroz I & $\mathrm{X}$ & & & & & & & $\mathrm{X}$ & & $\mathrm{X}$ \\
\hline Ed Queiroz II & $\mathrm{X}$ & & & & $\mathrm{X}$ & $\mathrm{X}$ & & & & $\mathrm{X}$ \\
\hline Farias Brito & $\mathrm{X}$ & & & & & & & $\mathrm{X}$ & $\mathrm{X}$ & $\mathrm{X}$ \\
\hline Jardim América & & & & & & $\mathrm{X}$ & & & & $\mathrm{X}$ \\
\hline Jardim das Oliveiras & $\mathrm{X}$ & & $\mathrm{X}$ & & $\mathrm{X}$ & $\mathrm{X}$ & & & $\mathrm{X}$ & $\mathrm{X}$ \\
\hline Lagoa Redonda & $\mathrm{X}$ & & & & & $\mathrm{X}$ & & & $\mathrm{X}$ & $\mathrm{X}$ \\
\hline Modumbim & $\mathrm{X}$ & & & & & $\mathrm{X}$ & & $\mathrm{X}$ & & $\mathrm{X}$ \\
\hline Palpina & $\mathrm{X}$ & & $\mathrm{X}$ & & & $\mathrm{X}$ & & & & $\mathrm{X}$ \\
\hline Passaré & $\mathrm{X}$ & & & & & $\mathrm{X}$ & Fox & & $\mathrm{X}$ & $\mathrm{X}$ \\
\hline Planalto Airton Senna & & & & & & & Rabbit & $\mathrm{X}$ & & $\mathrm{X}$ \\
\hline Quitino Cunha & $\mathrm{X}$ & & $\mathrm{X}$ & & & $\mathrm{X}$ & & & & $\mathrm{X}$ \\
\hline Siqueira & $\mathrm{X}$ & & $\mathrm{X}$ & & & $\mathrm{X}$ & & & & $\mathrm{X}$ \\
\hline Vicente Pizon & & & & & & $\mathrm{X}$ & & & & $\mathrm{X}$ \\
\hline Vila Man Sátiro & $\mathrm{X}$ & & & & & & & & & $\mathrm{X}$ \\
\hline José Walter & $\mathrm{X}$ & & & & & $\mathrm{X}$ & & & & $\mathrm{X}$ \\
\hline
\end{tabular}

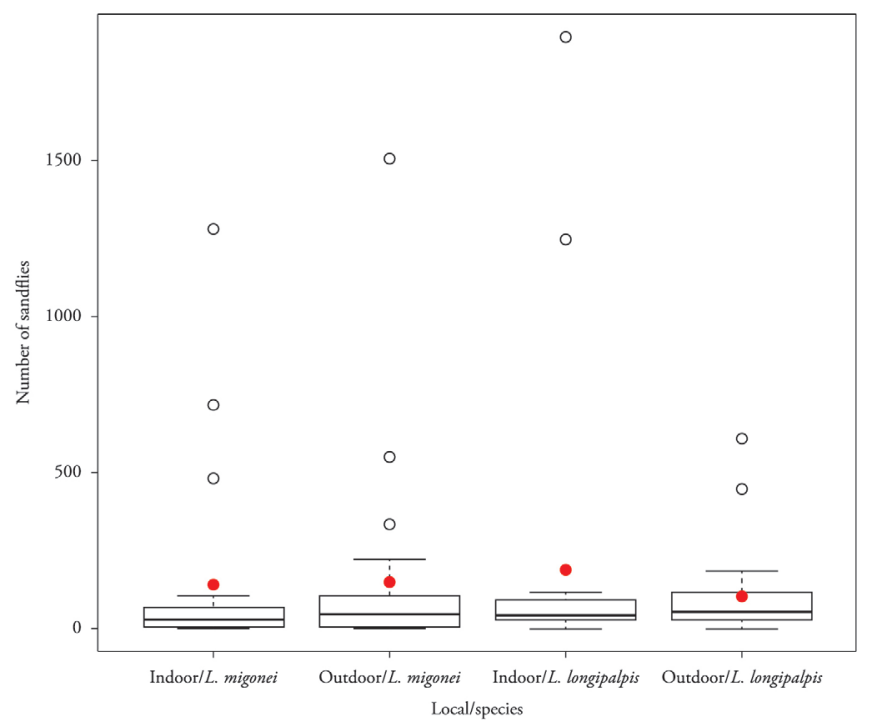

Figure 2. Box-plot of the number of female sandflies by local (indoor and outdoor) and species (Lutzomyia longipalpis and Lutzomyia migonei). Fortaleza, Ceará, Brazil.

\section{Lutzomyia migonei}

A total of 14,237 specimens of L. migonei were captured; $6,727(47.25 \%)$ of these were caught indoors and 7,510 $(52.75 \%)$ outdoors (Table 1). These values were significantly different $(\mathrm{p}=$ 0.0012). Similar to L. longipalpis, the density of $L$. migonei was the highest in FB, as 2,800 (41.62\%) samples were collected indoors and 1,211 (16.13\%) were collected outdoors. The district of VP had the lowest neighborhood density of $0(0 \%)$ indoors and 3 outdoors $(0.04 \%)$. Male flies were predominant, but the male/ female ratio was slightly lower, at 1.23 , than it was for L. longipalpis. There was no correlation between the number of cases and vector density in this region (Tables 3 and 4).

\section{Discussion}

The urbanization of visceral leishmaniasis has been extensively studied and is related to environmental changes caused by human action, the intense process of rural-urban migration and the interaction between susceptible individuals (LAINSON, 1989; SILVA et al. 1997; DIAS et al. 2003; TAUIL, 2006; MAIA-ELKHOURY et al., 2008). However, an important factor determining the expansion and urbanization of $\mathrm{VL}$ is the enormous adaptability of the main vector, L. longipalpis, to a changing environment (RANGEL; VILELA, 2008; RANGEL; LAINSON, 2009).

This present study, conducted in Fortaleza, documented the presence of these species at each of the 22 sites examined, which supports the wide distribution of these vectors. The species appear to be fully adapted to the urban areas of Fortaleza due to the negligible differences in density between the studied area. This adaptation is of concern due to the increased interactions between the vector and susceptible individuals, who could make it difficult to prevent and control disease. This study also demonstrated a 
Table 3. Correlation among canine and human cases, sex of Lutzomyia longipalpis and Lutzomyia longipalpis specimens collected indoors and outdoors.

\begin{tabular}{llcccccc}
\hline & & Human cases & male & female & Indoor & Outdoor & Total \\
\hline Canine cases & Pearsons' Correlation & 0.162 & 0.078 & 0.099 & 0.139 & -0.095 & 0.086 \\
& $\mathrm{p}$ & 0.472 & 0.73 & 0.662 & 0.537 & 0.673 & 0.704 \\
& $\mathrm{~N}$ & 22 & 22 & 22 & 22 & 22 & 22 \\
Human cases & Pearsons' Correlation & & -0.056 & -0.072 & -0.144 & 0.199 & -0.062 \\
& $\mathrm{p}$ & & 0.804 & 0.751 & 0.522 & 0.374 & 0.784 \\
& $\mathrm{~N}$ & & 22 & 22 & 22 & 22 & 22 \\
\hline
\end{tabular}

Values of $\mathrm{p} \leq 0.05$ indicate significant correlation.

Table 4. Correlation among canine and human cases, sex of Lutzomyia migonei and Lutzomyia migonei specimens collected indoors and outdoors.

\begin{tabular}{llcccccc}
\hline & & Human cases & Male & Female & Indoor & Outdoor & Total \\
\hline Canine cases & Pearsons' Correlation & 0.162 & 0.104 & 0.18 & 0.047 & 0.212 & 0.141 \\
& $\mathrm{P}$ & 0.472 & 0.644 & 0.424 & 0.834 & 0.344 & 0.532 \\
& $\mathrm{~N}$ & 22 & 22 & 22 & 22 & 22 & 22 \\
Human cases & Pearsons' Correlation & & -0.036 & -0.029 & -0.147 & 0.088 & -0.033 \\
& $\mathrm{P}$ & & 0.872 & 0.898 & 0.515 & 0.697 & 0.884 \\
& $\mathrm{~N}$ & & 22 & 22 & 22 & 22 & 22 \\
\hline
\end{tabular}

Values of $\mathrm{p} \leq 0.05$ indicate significant correlation.

high vector density (56\%), as there were significant differences between L. longipalpis and L. migonei densities $(\mathrm{p}<0.0001)$. These results corroborate those of Oliveira et al. (2006, 2008), who found L. longipalpis to be the most prevalent species (92.2\%) in Campo Grande city, Mato Grosso do Sul State, and to have a high density and degree of adaptation in this city.

With regard to the socio-environmental factors that may contribute to the emergence of sand flies, the work by Fernández et al. (2010) in the city of Posadas in the Misiones province of Argentina found that factors related to the routine capture of sand flies, such as the presence or absence of electric light, may influence vector sample density. We observed large differences in the density of each vector species among collection points with similar environmental characteristics, such as vegetation and the presence of domesticated animals. The largest number of specimens was collected in the northern area of FB and the southern area of MD. These large densities may be due to the size of the property and/or the diversity of plant and animal species because these collection points had the largest areas and the greatest plant and animal diversity. Thus, further analyses of the local environmental characteristics must be included in future studies that use local capture. The smallest number of collected specimens of both species occurred in the VP district, which is justified by its location near the beach, in the presence of strong winds.

Lutzomyia migonei is a species found mainly in the wild or in outdoor environments and is mainly associated with the transmission of cutaneous leishmaniasis, as this species is endowed with a remarkable degree of anthropophilicity (QUEIROZ et al. 1994; PITA-PEREIRA et al., 2005; RANGEL; LAINSON, 2009). However, recent studies have found that L. migonei participates in the transmission of VL. Indeed, L. migonei possesses the three essential characteristics of vector competence, including anthropophily, distribution coincident with human cases and evidence of natural infection with $L$. (L.) infantum chagasi
(KILLICK-KENDRICK, 1990). Studies in La Banda, Argentina, have shown L. migonei to be the predominant species (93\%) in areas with indigenous cases of $\mathrm{VL}$ and an absence of $L$. longipalpis and L. cruzi, the last of which is another potential vector of VL in Central Brazil (SALOMÓN et al., 2010). An enzootic cycle of VL and accidental transmission to humans was suggested for this sand fly vector (SALOMÓN et al., 2010). There are similar reports from San Vicente Ferrer in the State of Pernambuco, Brazil, and the natural infection of this species by $L$. (L.) infantum chagasi has been documented (CARVALHO et al., 2007, 2010).

In the epidemiological scenario of VL in Brazil, the city of Fortaleza has been highlighted by urban transmission, with high numbers of human and canine cases of the disease. The simultaneous occurrence of $L$. migonei and L. longipalpis in the local transmission of $\mathrm{VL}$ in this city, a fact already detected by the actions of entomological State Department of Health, is also worth mentioning.

The results of this study suggest changes in the urban behavior of L. migonei; this vector was found at a high density (44\%) in all collection points but specifically with a high level of infestation both indoors (90.90\%) and outdoors (95.45\%), suggestive of an adaptation to the environment in and around residences. In previous studies, it was observed that $L$. migonei had a wild behavior, as it was found in abundance in forests, usually in areas with abundant vegetation (RANGEL; LAINSON, 2003). Based on the analysis of entomological indicators (index of relative abundance and level of home infestation), there were no differences in density between the species, as both were found at high densities indoors and outdoors. This suggests that these two species share the role of vector in the transmission of VL. Due to the scant difference in the densities of these species between the regions studied, they are assumed to be fully adapted to the urban area of Fortaleza. Considering the high prevalence of canines in the city of Fortaleza, this adaptation process is of concern with 
regard to the increased interaction among the vector, the domestic reservoir and susceptible individuals, making it challenging to prevent and control this disease.

The male-to-female ratio in this study was 1.23 for L. migonei and 1.85 for $L$. longipalpis, indicating the predominance of males described previously (CASTELLÓN et al. 1989; CABANILLAS; CASTELLÓN, 1999; XIMENES et al., 2000; CORTEZ et al., 2007). This could be because males are born earlier than females (CHANIOTIS, 1967) or due to the courtship behavior between males and females (KELLY; DYE, 1997).

Although we found no correlation between L. migonei and L. longipalpis density and the occurrence of human or canine VL, L. migonei and L. longipalpis cannot be considered to be excluded from participating in the transmission of VL in Fortaleza because additional factors, such as parasite load in the vector population, determine disease transmission (MEDLEY, 1992). Additionally, the delayed reporting of cases or the incubation period of the disease, which can vary up to one year, may explain this lack of correlation (ZERPA et al., 2003; BERN et al. 2008).

The results of this study in combination with information in the literature may suggest $L$. migonei as a potential vector of $\mathrm{VL}$ in Fortaleza. However, research into the natural infection of L. migonei by Leishmania sp. could in fact evaluate the real role of each species, i.e., L. longipalpis and L. migonei, in the local epidemiology of VL.

It is essential to further study the behavior and distribution of this species for the correct implementation of vector control and prevention of VL.

Within this context and considering the possibility of another sand fly vector transmitting VL, the analysis of entomological indicators should be performed periodically, especially to assess progress in epidemiology and environmental assistance in expanding areas of transmission.

\section{Acknowledgements}

We thank the entomology team from the Center for Vector Control and the Health Department of Ceará State. In particular, we thank Oseas Ribeiro de Queiroz, José Maria Paz Araujo, Neilton Moteiro Pascoal, Agostinho Gomes de Sousa, Asevedo Quirino de Sousa and Dr. Manuel Dias da Fonseca Neto; their technical assistance was essential to the completion of this study. Dr. Claudia Maria Leal Bevilaqua and Dr. Elizabeth Ferreira Rangel have a grant from CNPq.

\section{References}

Bern C, Maguire JH, Alvar J. Complexities of assessing the disease burden attributable to leishmaniasis. PLoS Negl Trop Dis. 2008; 2(10): e313. http://dx.doi.org/10.1371/journal.pntd.0000313. PMid:18958165

Brasil. Ministério da Saúde. Secretaria de Vigilância em Saúde. Departamento de Vigilância Epidemiológica. Manual de vigilância e controle da leishmaniose visceral. Brasília; 2006. 816 p. Série A. Normas e Manuais Técnicos.

Brasil. Ministério da Saúde. Secretaria de Vigilância em Saúde. Departamento de Vigilância Epidemiológica. Guia de vigilância epidemiológica. 7. ed. Brasília; 2009. 816 p. Série A. Normas e Manuais Técnicos.

Cabanillas MRS, Castellón EG. Distribution of sandflies (Diptera:Psychodidae) on tree-trunks in a non-flooded area of the Ducke Forest Reserve, Manaus, AM, Brazil. Mem Inst Oswaldo Cruz. 1999; 94(3): 289-296. http://dx.doi.org/10.1590/S007402761999000300003. PMid:10348977

Carvalho MR, Lima BS, Marinho-Júnior JF, Silva FJ, Valença HF, Almeida FA, et al. Phlebotomine sandfly species from an American visceral leishmaniasis area in the Northern Rainforest region of Pernambuco State, Brazil. Cad Saude Publica. 2007; 23(5): 1227-1232. http://dx.doi. org/10.1590/S0102-311X2007000500024. PMid:17486244

Carvalho MR, Valença HF, Silva FJ, Pita-Pereira D, Araújo Pereira T, Britto C, et al. Natural Leishmania infantum infection in Migonemyia migonei (França, 1920) (Diptera:Psychodidae:Phlebotominae) the putative vector of visceral leishmaniasis in Pernambuco State, Brazil. Acta Trop. 2010; 116(1): 108-110. http://dx.doi.org/10.1016/j. actatropica.2010.03.009. PMid:20457120

Castellón EG, Araújo-Filho NA, Fé NF, Alves JMC. Flebotomíneos (Diptera: Psychodidae) no Estado de Roraima, Brasil. I. Espécies coletadas nas regiôes Sul e Central. Mem Inst Oswaldo Cruz. 1989; 84(S4): 95-99. http://dx.doi.org/10.1590/S0074-02761989000800021. PMid:2108309

Chaniotis BN. The biology of California Phlebotomus (Diptera: Psychodidae) under laboratory conditions. J Med Entomol. 1967; 4(2): 221-233. PMid:6052128.

Cortez AM, Silva VPM, Queiroz PVS, Andrade HTA, Loiola MIB, Ximenes MFFM. Vertical stratification and development aspects of phlebotomine sand flies (Diptera: Psychodidae) in an area of Atlantic Forest tree species in a metropolitan region in northeastern Brazil. $J$ Vector Ecol. 2007; 32(2): 336-341. http://dx.doi.org/10.3376/10811710(2007)32[336:VSADAO]2.0.CO;2. PMid:18260526

Deane LM. Leishmaniose Visceral no Brasil. Rio de Janeiro: Serviço Nacional de Educação Sanitária; 1956.

Demidenko E. Mixed Models: Theory and Applications. New York: Wiley; 2004.. http://dx.doi.org/10.1002/0471728438.

Dias FO, Lorosa ES, Rebêlo JM. Blood feeding sources and peridomiciliation of Lutzomyia longipalpis (Lutz \& Neiva, 1912) (Psychodidae, Phlebotominae). Cad Saude Publica. 2003; 19(5): 1373-1380. http://dx.doi.org/10.1590/S0102-311X2003000500015. PMid:14666218

Fernández MS, Salomón OD, Cavia R, Perez AA, Acardi SA, Guccione JD. Lutzomyia longipalpis spatial distribution and association with environmental variables in an urban focus of visceral leishmaniasis, Misiones, Argentina. Acta Trop. 2010; 114(2): 81-87. http://dx.doi. org/10.1016/j.actatropica.2010.01.008. PMid:20096256

Galati EA, Nunes VL, Rego Júnior FA, Oshiro ET, Chang MR. Phlebotomines (Diptera: Psychodidae) focusing visceral leishmaniasis in the State of Mato Grosso do Sul, Brazil. Rev Saude Publica. 1997; 31(4): 378-390. http://dx.doi.org/10.1590/S0034-89101997000400007. PMid:9595767

Galati EAB. Morfologia e Taxonomia. In: Rangel EF, Lainson R. Flebotomineos do Brasil. Rio de Janeiro: Fiocruz; 2003. p. 23-51.

Instituto Brasileiro de Geografia e Estatística - IBGE. [online]. 2008 [cited 2009 Oct 01]. Available from: http://www.ibge.gov.br/home/ presidencia/noticias/noticia_impressao.php?id_noticia=1215. 
Kelly DW, Dye C. Pheromones, Kairomones and the aggregation dynamics of the sandfly Lutzomyia longipalpis. Anim Behav. 1997; 53(4): 721-731. http://dx.doi.org/10.1006/anbe.1996.0309.

Killick-Kendrick R. Phlebotomine vectors of the leishmaniases: a review. Med Vet Entomol. 1990; 4(1): 1-24. http://dx.doi. org/10.1111/j.1365-2915.1990.tb00255.x. PMid:2132963

Lainson R. Demographic changes and their influence on the epidemiology of the American leishmaniases. In: Service MW. Demography and vectorborne diseases. Boca Raton: CRC Press; 1989. p. 85-106.

Lainson R, Rangel EF. Lutzomyia longipalpis and the eco-epidemiology of American visceral leishmaniasis, with particular reference to Brazil: a review. Mem Inst Oswaldo Cruz. 2005; 100(8): 811-827. http://dx.doi. org/10.1590/S0074-02762005000800001. PMid:16444411

Maia-Elkhoury AN, Alves WA, Sousa-Gomes ML, Sena JM, Luna EA. Visceral leishmaniasis in Brazil: trends and challenges. Cad Saude Publica. 2008; 24(12): 2941-2947. http://dx.doi.org/10.1590/S0102311X2008001200024. PMid:19082286

Medley GF. Which comes first in host-parasite systems: density dependence or parasite distribution? Parasitol Today. 1992; 8(10): 321-322. http://dx.doi.org/10.1016/0169-4758(92)90061-6. PMid:15463525

Oliveira AG, Galati EA, Oliveira O, Oliveira GR, Espindola IA, Dorval ME, et al. Abundance of Lutzomyia longipalpis (Diptera: Psychodidae: Phlebotominae) and urban transmission of visceral leishmaniasis in Campo Grande, state of Mato Grosso do Sul, Brazil. Mem Inst Oswaldo Cruz. 2006; 101(8): 869-874. http://dx.doi.org/10.1590/S007402762006000800008. PMid:17293981

Oliveira AG, Galati EAB, Fernandes CE, Dorval MEC, Brazil RP. Seasonal variation of Lutzomyia longipalpis (Lutz \& Neiva, 1912) (Diptera: Psychodidae: Phlebotominae) in endemic area of visceral leishmaniasis, Campo Grande, state of Mato Grosso do Sul, Brazil. Acta Trop. 2008; 105(1): 55-61. http://dx.doi.org/10.1016/j. actatropica.2007.09.008. PMid:18022137

Pita-Pereira D, Alves CR, Souza MB, Brazil RP, Bertho AL, Figueiredo Barbosa A, et al. Identification of naturally infected Lutzomyia intermedia and Lutzomyia migonei with Leishmania (Viannia) braziliensis in Rio de Janeiro (Brazil) revealed by a PCR multiplex non-isotopic hybridisation assay. Trans R Soc Trop Med Hyg. 2005; 99(12): 905-913. http://dx.doi. org/10.1016/j.trstmh.2005.06.019. PMid:16143358

Queiroz RG, Vasconcelos IA, Vasconcelos AW, Pessoa FA, de Sousa RN, David JR. Cutaneous leishmaniasis in Ceara state in northeastern Brazil: incrimination of Lutzomyia whitmani (Diptera: Psychodidae) as a vector of Leishmania braziliensis in baturite municipality. Am J Trop Med Hyg. 1994; 50(6): 693-698. PMid:8024061.

Rangel EFR, Lainson R. Ecologia das Leishmanioses. In: Rangel EF, Laison R. Flebotomíneos do Brasil. Rio de Janeiro: Fiocruz; 2003. p. 291-336.
Rangel EF, Vilela ML. Lutzomyia longipalpis (Diptera, Psychodidae, Phlebotominae) and urbanization of visceral leishmaniasis in Brazil. Cad Saude Publica. 2008; 24(12): 2948-2952. http://dx.doi.org/10.1590/ S0102-311X2008001200025. PMid:19082287

Rangel EF, Lainson R. Proven and putative vectors of American cutaneous leishmaniasis in Brazil: aspects of their biology and vectorial competence. Mem Inst Oswaldo Cruz. 2009; 104(7): 937-954. http:// dx.doi.org/10.1590/S0074-02762009000700001. PMid:20027458

Ribeiro ALM, Missawa NA, Zeilhofer P. Distribution of phlebotomine sandflies (Diptera: Psychodidae) of medical importance in Mato Grosso State, Brazil. Rev Inst Med Trop Sao Paulo. 2007; 49(5): 317-321. http:// dx.doi.org/10.1590/S0036-46652007000500008. PMid:18026639

Salomón OD, Quintana MG, Bezzi G, Morán ML, Betbeder E, Valdéz DV. Lutzomyia migonei as putative vector of visceral leishmaniasis in La Banda, Argentina. Acta Trop. 2010; 113(1): 84-87. http://dx.doi. org/10.1016/j.actatropica.2009.08.024. PMid:19716797

Santos SO, Arias J, Ribeiro AA, de Paiva Hoffmann M, de Freitas RA, Malacco MA. Incrimination of Lutzomyia cruzi as a vector of American visceral leishmaniasis. Med Vet Entomol. 1998; 12(3): 315-317. http:// dx.doi.org/10.1046/j.1365-2915.1998.00104.x. PMid:9737605

Silva AR, Viana GM, Varonil C, Pires B, Nascimento MD, Costa JML. Visceral leishmaniasis (kala-azar) on Ilha de São Luís, Maranhão. Brazil: its evolution and outlook. Rev Soc Bras Med Trop. 1997; 30(5): 359-368. PMid:9380895.

Sudia WD, Chamberlain RW. Battery operated light trap, an improved model. Mosq News. 1962; 22(2): 126-129.

Tauil PL. Perspectives of vector borne diseases control in Brazil. Rev Soc Bras Med Trop. 2006; 39(3): 275-277. PMid:16906253.

Vilela ML, Rangel EFR, Lainson R. Métodos de coleta e preservação de flebotomíneos. In: Rangel EF, Laison R. Flebotomíneos do Brasil. Rio de Janeiro: Fiocruz; 2003. p. 353-367.

Ximenes MFFM, Castellón EG, de Souza MF, Freitas RA, Pearson RD, Wilson ME, et al. Distribution of phlebotomine sand flies (Diptera: Psychodidae) in the state of Rio Grande do Norte, Brazil. J Med Entomol. 2000; 37(1): 162-169. http://dx.doi.org/10.1603/0022-2585-37.1.162. PMid:15218921

Young DG, Duncan MA. Guide to the Identification and Geographic Distribution of Lutzomyia Sand Flies in Mexico, the West Indies, Central and South America (Diptera: Psychodidae). Mem Amer Inst Entomol 1994; (54):1-881.

Zerpa O, Ulrich M, Borges R, Rodríguez V, Centeno M, Negrón E, et al. Epidemiological aspects of human and canine visceral leishmaniasis in Venezuela. Rev Panam Salud Publica. 2003; 13(4): 239-245. http:// dx.doi.org/10.1590/S1020-49892003000300006. PMid:12804153 